\title{
Pequeñas crónicas del domingo en la noche. Entrevista de Michel Polacco a Michel Serres*
}

\author{
Traducción del francés al español de \\ Luis Alfonso Paláu-Castaño \\ Universidad Nacional de Colombia, Medellín, Colombia \\ laPalau@une.net.co
}

\section{Los cementerios \\ Crónica del 30 de octubre de 2005}

Polacco: Michel Serres, esta semana hablemos de los cementerios. Nada hay más alegre, pero en esta víspera de Todos los Santos, luego de fiesta de los Muertos, numerosos son los que van a llevar flores, a recogerse allí un momento. Cementerios que existen desde que el hombre abandonó la animalidad, que de alguna manera son la marca de su entrada en civilización. Ocuparse de sus muertos es lo propio del hombre.

Serres: Nos hemos vuelto los hombres que somos cuando descubrimos, no sé ni cuándo ni cómo, que habríamos de morir; que nuestros parientes, que las gentes que amamos habrían de morir. Para la fiesta de Muertos, entremos hoy en nuestros cementerios. Ha notado hasta qué punto se parecen a ciudades, con sus calles, sus plazas, sus avenidas, sus inmuebles de familia...

Polacco: (...) con sus capillas a veces...

Serres: (...) con sus barrios de ricos y sus barrios de pobres. Metrópolis, necrópolis. Para comprender el cementerio, por el contrario, salgamos de la ciudad, e incluso de este agrupamiento, casi pueblerino, de tumbas. Para salir mejor, quiero decir una palabra. Las palabras son cajas de Pandora; cuando se las abre nos encontramos con que su sentido prolifera a veces. Me tomo la libertad de decir una palabra latina: pagus. ¿Qué significa? El campo labrantío, el cuadrado o el rectángulo de alfalfa, el campo de trigo, la pieza de maíz, el pedazo de viña, el jardín dividido en planos de tomates y de lechugas. Este pagus, apasionante, ha producido dos palabras, tres, cuatro, diez palabras en las lenguas romances. Aquí tenemos las primeras: "país" y "paisaje". Admirad

* Cómo citar: Serres, M. (2019). Pequeñas crónicas del domingo en la noche. Entrevista de Michel Polacco a Michel Serres. Ciencias Sociales y Educación, 8(15), 293-295. DOI: https://doi.org/10.22395/csye.v8n15a16

Agradecemos a Le Pommier por posibilitar la publicación de la traducción al español del texto del filósofo e historiador de las ciencias, Michel Serres. La traducción la realizó el profesor Luis Alfonso Paláu-Castaño en octubre de 2013 y se publica por vez primera en la presente edición de la revista (nota del editor).

Recibido: 20 de febrero de 2019.

Aprobado: 26 de abril de 2019. 
el paisaje, constituido en efecto como un abrigo de arlequín, con rectángulos y cuadrados yuxtapuestos, de alfalfa, de maíz, separados por setos, sembrados de florestas, etc., como un tejido cosido. Este es el paisaje. Y ¿qué es un paisano, aún formado sobre la misma palabra: "país", "paisaje"? El paisano dibujó, dibuja y dibujará el paisaje; esculpe el país. Pagus, paisano, paisaje. Los más bellos paisajes del mundo, los de mi sudoeste natal, los de la Toscana, los de las riberas del Yange-tse, han sido fabricados, esculpidos, dibujados y pintados por esos artistas sublimes que el mundo siempre ha olvidado, que se llaman los campesinos.

Polacco: Estamos alejándonos del cementerio.

Serres: Ya voy a regresar. El paisano hace el paisaje. Ahora bien, el pagus ha dado otras palabras distintas a estas palabras mundiales: "paisa", "paisaje"; ha producido las palabras "pagano" y "paganismo" tenemos ahora pues lo religioso. ¿Por qué? Porque cada pagus, cada pedazo de cultivo tiene su dios. ¿Cuál es ese dios que gobierna y designa el pagus? Es el ancestro enterrado al fondo del campo labrantío. He aquí desde el origen, el elemento del cementerio. Ese cuadrado labrado, que hace la pieza del paisaje, es también el elemento del paganismo, porque para las más antiguas creencias, cada pedazo de tierra está fecundado, fertilizado, por la carne, el sudor y la sangre de los ancestros campesinos.

\section{Polacco: Es muy simbólico.}

Serres: Así, La Fontaine lo cuenta en "El labrador y sus hijos". In articulo mortis, el labrador dice a sus hijos: "tomaos la pena de trabajar; en el fundo al que menos le falta (...) un tesoro está oculto en él". El fabulista dice que el trabajo es un tesoro, le quita la palabra al labrador en el momento que va a decir el secreto. Y este es el secreto: en el pagus, en el pedazo labrantío, hay verdaderamente un tesoro, y no es el trabajo, es el ancestro enterrado ahí, que hace que el pedazo de tierra sea la propiedad de la familia, el lugar de ritos donde la familia ora y se recoge, el lugar religioso, el elemento de paisaje al mismo tiempo que el elemento de paganismo. La expresión "aquí yace", hic jacet, quiere decir que "no hay lugar aquí, en la tierra y en el mundo, no hay tierra en el mundo, más que si y solamente si un ancestro está enterrado en ella". Aquel que yace, el viejo labrador que está muriendo, designa el "hic", el lugar aquí; aquí, quiero yacer con los ancestros. Y este es vuestro lugar, porque aquí reposaré con ellos. El dios del paganismo reposa aquí; debéis rendirle un culto.

Polacco: Pero el cementerio les reúne, a los que yacen. 
Serres: Henos pues a nosotros, gentes de ciudad, que llamamos hoy cementerio a ese antiguo paisaje, a este agrupamiento, a esta asociación, a este jirón recocido de los pagus paisanos y paganos. Distribuidos antaño en el paisaje rural, aquellos lugares de paganismo... vea pues apurado por usted me olvidé de decirle una última palabra salida de pagus: la paz. La silenciosa paz del paisaje, el silencio apacible de los cementerios. Dados los límites asignados a los campos labrantíos, a los pedazos de caña de azúcar, a los cultivos de papa, dados los límites asignados a los lugares donde están enterrados los ancestros de cada uno, entonces nadie hará la guerra contra sus vecinos porque tratará de no ultrapasar los límites. En suma final, ¿qué es un cementerio? La reunión apretada en medio de una ciudad de todos los antiguos pagus de la rusticidad. La ciudad restituye, por medio del cementerio, el antiguo, el arcaico, el tradicional paisaje de los paisanos y del paganismo, completamente olvidado, la paz del exterior de la ciudad, el país mismo, antiguamente hecho de esas piezas ensambladas, del cosido de esos campos y de esas tumbas dispersas que marcaban la propiedad de cada familia. Todos los pagus están allá, construidos, todos los lugares de entierro, todos los "aquí". Entonces, el cementerio, del que creíamos hace un rato que se parecía a una ciudad, imita por el contrario el antiguo paisaje de campiña, reuniendo la totalidad de las tumbas campesinas apretadas. Por esto la paz silenciosa que mana de él. Pero, inversamente también, la ciudad misma, la metrópolis imita la necrópolis: su apartamento se construye aquí en el pedazo de tierra que le pertenece a usted.

Polacco: En este caso, ¿cómo podemos ir hacia... el "fin de los cementerios"? Las gentes se hacen incinerar cada vez más, se abandona progresivamente el culto de los muertos...

Serres: ¿Nos falta sitio? Se dice que las cenizas ocupan menos lugar que los cuerpos. No. Déjeme terminar mencionando dos ritos opuestos: el enterramiento de los cuerpos amados hacía pues sagrada la tierra; de la misma manera el cuerpo se volvía sagrado porque el hombre -homo, humus- se decía estaba hecho de tierra. Lo sagrado antiguo tiene pues que ver con lo que he dicho del pagus, del antiguo paganismo, de su adhesión mortal a la muerte. De forma inversa, una religión moderna como el cristianismo, celebra la tumba vacía. Dice: "dejad a los muertos que entierren a los muertos". Olvidemos la muerte vivamos la vida. Me gustaría, si se quiere, pues ello me da lo mismo, que se dispersen mis cenizas; sí, en el corredor Coolidge, por ejemplo, en esa chimenea vertiginosa de hielo donde, como alpinista que comenzaba con aquella ascensión, el alba me agarró repentinamente y me envolvió con su color violeta y malva; allá con lágrimas en los ojos dije: "luz de luz".

Polacco: Permanezcamos pues sobre esta bellísima luz. Gracias Michel Serres. 